\title{
Analisa Data Penjualan SaRa Collection menggunakan metode Apriori
}

\author{
Ririn Restu Aria ${ }^{1}$, Susi Susilowati \\ 1,2 Universitas Bina Sarana Informatika \\ 1e-mail: ririn.rra@bsi.ac.id \\ 2e-mail: susi.sss@bsi.ac.id

\begin{tabular}{ccc} 
Diterima & Direvisi & Disetujui \\
$21-11-2020$ & $22-12-2020$ & $24-01-2021$ \\
\hline
\end{tabular}

\begin{abstract}
Abstrak - Penjualan adalah salah satu hal terpenting dalam SaRa collection. Untuk meningkatkan jumlah penjualan yang ada, SaRa collection harus bisa melihat peluang dan kebutuhan yang diperlukan oleh konsumen yang dimilikinya. Untuk itu disaat pandemi Covid 19 yang terjadi sekarang, SaRa collection membuat konektor yang bisa digunakan untuk mempercantik penggunaan masker guna mencegah penularan virus Covid 19. Dalam proses pembuatan konektor masih dilakukan secara homemade sesuai dengan model yang diminati oleh konsumen karena butuh waktu pengerjaan dan pemilihan model serta warna yang sesuai. Saat ini penjualan yang dilakukan masih dilakukan pencatatan secara manual sehingga pemilik masih kesulitan untuk menyediakan stok model dan warna konektor yang akan dibuat agar bisa memenuhi permintaan konsumen. Agar bisa mengetahui model apa aja yang harus disediakan maka diperlukan perhitungan yang akurat, untuk itu penulis menggunakan algoritma apriori sebagai metode tersebut diharapkan dapat menjadi bahan pertimbangan dalam strategi pemasaran dan penjualan serta data stok penghubung yang akan dibuat. Perhitungan apriori dengan itemset dan asosiasi berdasarkan data transaksi penjualan di SaRa collection
\end{abstract}

Kata Kunci: Penjualan,Data mining,Metode Apriori

Abstract - Sales are one of the most important things in the SaRa collection. To increase the number of existing sales, SaRa collection must be able to see the opportunities and needs needed by its customers. For this reason, when the Covid 19 pandemic is happening now, the SaRa collection has made a connector that can be used to beautify the use of masks to prevent transmission of the Covid 19 virus. In the process of making the connector, it is still done homemade according to the model that consumers are interested in because it takes time to process and select the model. as well as the appropriate color. Currently, sales are still being recorded manually, so the owner is still having trouble providing a stock of the connector model and color that will be made in order to meet consumer demand. In order to find out what models must be provided, accurate calculations are needed, for that the author uses the a priori algorithm as a method which is expected to be taken into consideration in marketing and sales strategies as well as connecting stock data to be made. A priori calculations with itemset and associations based on sales transaction data in Sara's collection

Keywords: Sales, Data mining, Apriori Method

\section{PENDAHULUAN}

SaRa collection merupakan usaha yang berawal dari sebuah hobi dibidang merajut. SaRa collection merupakan salah satu toko yang menjual konektor sebagai pelengkap penggunaan masker dengan berbagai jenis model dan warna yang bisa dipilih pembeli saat memesann produk tersebut. Proses pembuatan konektor saat ini dikerjakan secara homemade sehingga akan memberikan hasil yang memuaskan. Pada tahap awal pemilik memasarkan produk yang dibuat kepada teman - teman disekitar rumah dan kenalan dari pemilik, Tetapi untuk lebih meluaskan target pasar dan pembeli maka produk juga ditawarkan dengan media sosial melalui whatsapp,facebook. Kini produk dari konektor SaRa collection juga sudah selalu dipesan oleh toko jilbab,masker dan gamis untuk melengkapi koleksi mereka. Dimasa pandemi Covid 19, penjualan masker semakin meningkat karena diperlukan untuk mencegah penularan Covid 19. Untuk memudahkan pengguna dalam menggunakan masker, diperlukan konektor agar terlihat lebih modis dan cantik terutama untuk wanita yang berhijab. Selama ini data penjualan hanya dicatat secara manual sebagai rekap penjualan berdasarkan periode harian dan bulanan. Akan tetapi karena permintaan yang semakin meningkat membutuhkan pengolahan data mining apriori sehingga dapat menganalisa model apa yang paling banyak dibeli dan warna yang dipilih sehingga lebih mudah untuk mengolahnya menjadi informasi. yang nantinya digunakan untuk dapat meningkatkan penjualan dan pemasaran produk tersebut. 
Data mining adalah proses pencarian pola tersembunyi (hidden pattern) berupa pengetahuan (knowledge) yang sebelumnya tidak diketahui dari sekumpulan data dimana datanya dapat berada dalam database, data gudang, atau media penyimpanan informasi lainnya (Kusrini, 2009). Dengan menggunakan data mining maka akan didapatkan suatu pengetahuan didalam kumpulan data - data yang banyak tersebut. Salah satu penerapan data mining adalah dibidang penjualan produk (Bella Audi Najib, 2020). Penggunaan data mining digunakan agar SaRa Collection bisa menentukan sasaran penjualan konektor secara tepat sehingga tidak menghabiskan waktu dan biaya untuk dapat mengetahui model yang banyak diminati oleh konsumen. Beberapa penelitian yang pernah dilakukan dalam menerapkan metode algoritma Apriori mengenai implementasi data mining untuk mengetahui pola pembelian obat menggunakan algoritma Apriori (Ulfha \& Amin, 2020)

Penerapan metode Apriori yang digunakan pada SaRa collection. Algoritma Apriori dapat digunakan untuk mengetahui model serta warna yang paling banyaj dipesan oleh konsumen, sehingga dapat dilakukan pengujian dengan menentukan parameter support $30 \%$ dan nilai confidence minimum yang diinginkan sehingga pemilik bisa menyediakan barang sesuai dengan keinginan pembeli. Masalah yang dialami oleh SaRa collection saat ini adalah bagaimana cara mengembangkan pemasaran untuk meningkatkan penjualan konektor.

\section{METODOLOGI PENELITIAN}

Penelitian ini menerapkan algoritma apriori pada dataset berupa data histori transaksi. Tahapantahapan penelitian adalah pengumpulan data, prapemrosesan data,analisis pola frekuensi tertinggi menggunakan algoritme apriori, pembentukan pola association rule,dan pengujian hasil eksperimen (Ariefana Ria Riszky, 2019)

\section{A. Data Mining}

Data mining adalah proses mengekstrasi informasi atau sesuatu yang penting atau menarik dari data yang ada di dalam database sehingga menghasilkan informasi yang sangat berharga (Nurdin, 2015). Metode ini telah sering digunakan di banyak perusahaan sebagai sarana untuk menemukan asosiasi produk dan meningkatkan strategi promosi penjualan mereka, sehingga dapat dibuat dengan mudah laporan tentang penempatan produk, harga, promosi, profitabilitas, dan item-item apa saja yang sering dibeli (Lestari, 2017).

Data mining mempunyai empat fungsi dasar, yaitu (Halfis, 2019)

1. Fungsi Prediksi (prediction)

Proses yang digunakan menentukan pola dari data dengan menggunakan beberapa variable agar bisa memprediksi variabel yang lainnya yang tidak diketahui jenis atau nilainya.

2. Fungsi Deskripsi (description)

Proses untuk menemukan suatu karakteristik penting dari data dalam suatu basis data.

3. Fungsi Klasisfikasi (classification)

Klasifikasi merupakan suatu proses untuk menemukan model atau fungsi untuk menggambarkan class atau konsep dari suatu data.

4. Fungsi Asosiasi (association)

Proses ini digunakan untuk menemukan suatu hubungan yang terdapat pada nilai atribut dari sekumpulan data

\section{B. Metode Apriori}

Algoritma Apriori adalah suatu algoritma dasar yang diusulkan oleh Agrawal \& Srikant pada tahun 1994 untuk penentuan frequent itemsets untuk aturan asosiasi boolean. Algoritma apriori termasuk jenis aturan asosiasi pada data mining. Aturan yang menyatakan asosiasi antara beberapa atribut sering disebut affinity analysis atau market basket analysis. Analisis asosiasi atau association rule mining adalah teknik data mining untuk menemukan aturan suatu kombinasi item. Salah satu tahap analisis asosiasi yang menarik perhatian banyak peneliti untuk menghasilkan algoritma yang efisien adalah analisis pola frequensi tinggi (frequent pattern mining). Penting tidaknya suatu asosiasi dapat diketahui dengan dua tolak ukur, yaitu : support dan confidence (Purnia \& Warnilah, 2017). Algoritma Apriori termasuk jenis analisis asosiasi pada data mining. Analisis asosiasi merupakan teknik yang digunakan untuk menemukan aturan aosiatif antara suatu kombinasi barang (Sinaga, 2019). Algoritma apriori yang bertujuan untuk menemukan frequent itemsets dijalankan pada sekumpulan data. Market basket analysis merupakan salah satu teknik dari data mining yang mempelajari tentang perilaku kebiasaan konsumen dalam membeli barang secara bersamaan dalam satu waktu (Sianturi, 2018)

\section{HASIL DAN PEMBAHASAN}

Model penjualan konektor yang dipesan atau dibeli oleh setiap pelanggan memiliki model yang berbeda dari setiap pemesanan yang dilakukan. Berikut merupakan data penjualan ini digunakan untuk membuat analisis model data persediaan yang harus disediakan oleh SaRa collection. Seperti yang terlihat pada tabel 1, Anda dapat melihat model konektor pada transaksi penjualan.

Tabel 1

Data penjualan Konektor

\begin{tabular}{|c|c|}
\hline No & \multicolumn{1}{|c|}{ Data model konektor } \\
\hline 1 & Fan, Wave model 1 Chain \\
\hline
\end{tabular}




\begin{tabular}{|c|l|}
\hline 2 & $\begin{array}{l}\text { Fan, Wave model 2,Popcorn Combination } \\
\text { Flowers }\end{array}$ \\
\hline 3 & Wave model 2,Popcorn, Chain \\
\hline 4 & Chain, Buckle, Popcorn \\
\hline 5 & Wave model 2, Buckle, Combination Flowers \\
\hline 6 & Popcorn, Wave model 2, Buckle \\
\hline 7 & Chain, Combination Flowers, Wave model 1 \\
\hline 8 & Popcorn, Fan, Combination Flowers \\
\hline 9 & Popcorn, Fan, Buckle \\
\hline 10 & Popcorn, Wave model 1, Chain \\
\hline 11 & Popcorn, Wave model 1, Wave model 2 \\
\hline 12 & Fan, Wave model 1, Chain \\
\hline 13 & Buckle, Wave model 1, Popcorn \\
\hline 14 & Combination Flowers, Chain, Fan \\
\hline 15 & Wave model 2, Fan \\
\hline 16 & Chain, Combination Flower, Popcorn \\
\hline 17 & Combination Flower, Buckle, Popcorn \\
\hline 18 & Popcorn, Fan, Chain \\
\hline 19 & Wave model 1, Buckle, Popcorn, Chain \\
\hline 20 & Buckle, Wave model 1, Combination Flowers \\
\hline Sumber SaRa collection (2020)
\end{tabular}

Sumber : SaRa collection (2020)

Order $\mathrm{C} 1$ atau disebut 1 Itemset dengan jumlah minimum support $=30 \%$. Rumusan itemset dapat ditulis sebagai berikut:

Support $(A)=\sum$ Transaksi mengandung $A$

$$
\text { ¿Transaksi } \quad 100 \%
$$

Support $($ Fan $)=\sum$ Transaksi mengandung (Fan)

$$
=\frac{\sum \text { Transaksi }}{20} \times 100 \%=40 \%
$$

Untuk hasil perhitungan bisa dilihat ditabel 2 itemset

Tabel 2

Itemset

\begin{tabular}{|l|c|c|}
\hline \multicolumn{1}{|c|}{ Itemset } & Qty & Support \\
\hline Fan & 8 & $40 \%$ \\
\hline Wave model 1 & 8 & $40 \%$ \\
\hline Wave model 2 & 6 & $30 \%$ \\
\hline Chain & 11 & $55 \%$ \\
\hline Buckle & 8 & $40 \%$ \\
\hline Popcorn & 12 & $60 \%$ \\
\hline Combination Flowers & 8 & $40 \%$ \\
\hline
\end{tabular}

Sumber : Aria \& Susilowati (2020)

Minimum support yang ditentukan adalah 30\%, maka kombinasi dari 2 itemset yang tidak memenuhi minimum support akan dihapus.
2 itemset

\begin{tabular}{|l|c|c|}
\hline \multicolumn{1}{|c|}{ Itemset } & Qty & Support \\
\hline Fan, Wave model 1 & 2 & $10 \%$ \\
\hline Fan, Wave model 2 & 2 & $10 \%$ \\
\hline Fan, Popcorn & 4 & $20 \%$ \\
\hline Fan, Combination Flowers & 3 & $15 \%$ \\
\hline Fan, Chain & 4 & $20 \%$ \\
\hline Fan, Buckle & 1 & $5 \%$ \\
\hline Wave model 1, Chain & 6 & $30 \%$ \\
\hline $\begin{array}{l}\text { Wave model 1, Combination } \\
\text { Flowers }\end{array}$ & 2 & $10 \%$ \\
\hline Wave model 1, Popcorn & 3 & $15 \%$ \\
\hline Wave model 1, Wave model 2 & 1 & $5 \%$ \\
\hline Wave model 1, Buckle & 3 & $15 \%$ \\
\hline Wave model 2, Popcorn & 3 & $15 \%$ \\
\hline $\begin{array}{l}\text { Wave model 2, Combination } \\
\text { Flowers }\end{array}$ & 2 & $10 \%$ \\
\hline Wave model 2, Buckle & 3 & $15 \%$ \\
\hline Chain, Popcorn & 7 & $35 \%$ \\
\hline Chain, Buckle & 2 & $10 \%$ \\
\hline Chain, Combination Flowers & 3 & $15 \%$ \\
\hline Combination Flowers, Popcorn & 5 & $5 \%$ \\
\hline Combination Flowers, Buckle & 3 & $15 \%$ \\
\hline Buckle, Popcorn & 6 & $30 \%$ \\
\hline Sumber : Ara \& Susiowati & & \\
\hline
\end{tabular}

Sumber : Aria \& Susilowati (2020)

Proses pembentukan $\mathrm{C} 3$ atau yang disebut dengan 3 item diatur dengan jumlah minimal support $=30 \%$. Dapat diselesaikan dengan rumus berikut:

Support $(A, B, C)=\sum$ Transaksi $A, B, C$

$$
\text { ETransaksi } \mathrm{x} 100 \%
$$

$$
\begin{aligned}
\text { Support }(A, B, C)= & \left.\sum \text { Transkasi Buckle,Popcorn, Chain }\right) \\
& =\underline{2} \quad \times 100 \%=10 \% \\
& 20
\end{aligned}
$$

Dari hasil perhitungan support 3 itemset tidak didapatkan hasil yang sesuai dengan batasan minimal support $=30 \%$ yang telah ditentukan sehingga pencarian nilai support dihentikan.

D. Pembentukan Asosiasi Akhir Setelah semua pola frekuensi tinggi ditemukan, maka aturan asosiasi yang dicari memenuhi persyaratan minimum untuk keyakinan dengan menghitung aturan keyakinan asosiatif.

$\mathrm{A} \rightarrow$ B. Keyakinan Minimum $=60 \%$.

Confidence $=P(A B)=\sum$ Transaksi $A$ dan $B$ $\sum$ Transaksi $A \quad$ x $100 \%$

\section{Tabel 3}


Berdasarkan nilai yang diperoleh dari 2 itemset diperoleh nilai kepercayaan sebagai berikut

Tabel 4

2 Combination

\begin{tabular}{|c|c|c|}
\hline \multicolumn{3}{|c|}{2 Combination } \\
\hline Rule & Support & Confidence \\
\hline $\begin{array}{l}\text { Jika membeli chain, } \\
\text { maka akan membeli } \\
\text { popcorn }\end{array}$ & $30 \%$ & $85,7 \%$ \\
\hline $\begin{array}{l}\text { Jika membeli } \\
\text { popcorn, maka akan } \\
\text { membeli chain }\end{array}$ & $30 \%$ & $60 \%$ \\
\hline $\begin{array}{l}\text { Jika membeli buckle, } \\
\text { maka akan membeli } \\
\text { popcorn }\end{array}$ & $30 \%$ & $75 \%$ \\
\hline $\begin{array}{l}\text { Jika membeli } \\
\text { popcorn, maka akan } \\
\text { membeli buckle }\end{array}$ & $30 \%$ & $60 \%$ \\
\hline
\end{tabular}

Sumber : Aria \& Susilowati (2020)

\section{E. Implementasi Tanagra}

Dalam menerapakan algoritma Apriori, penulis menggunakan aplikasi Tanagra yang digunakan untuk pengujian data penjualan yang ada di SaRa collection. Beberapa tahapan yang dilakukan

1. Menyiapkan data dalam bentuk Excell

Tabel 5

Data Penjualan berdasarkan model

\begin{tabular}{|c|c|c|c|c|c|c|c|}
\hline No & Fan & $\begin{array}{c}\text { Wave } \\
m 1\end{array}$ & $\begin{array}{c}\text { Wave } \\
m 2\end{array}$ & Chain & $\begin{array}{c}\text { Buc } \\
\text { kle }\end{array}$ & $\begin{array}{c}\text { Pop } \\
\text { corn }\end{array}$ & $\begin{array}{c}\text { Comb } \\
\text { flower }\end{array}$ \\
\hline 1 & 1 & 1 & 0 & 1 & 0 & 0 & 0 \\
\hline 2 & 1 & 0 & 1 & 0 & 0 & 1 & 1 \\
\hline 3 & 0 & 0 & 1 & 1 & 0 & 1 & 0 \\
\hline 4 & 0 & 0 & 0 & 1 & 1 & 1 & 0 \\
\hline 5 & 0 & 0 & 1 & 0 & 1 & 1 & 1 \\
\hline 6 & 0 & 0 & 1 & 0 & 1 & 1 & 0 \\
\hline 7 & 0 & 1 & 0 & 1 & 0 & 0 & 1 \\
\hline 8 & 1 & 0 & 0 & 0 & 0 & 1 & 1 \\
\hline 9 & 1 & 0 & 0 & 0 & 1 & 1 & 0 \\
\hline 10 & 0 & 1 & 0 & 1 & 0 & 1 & 0 \\
\hline 11 & 0 & 1 & 0 & 1 & 0 & 1 & 0 \\
\hline 12 & 1 & 1 & 0 & 1 & 0 & 0 & 0 \\
\hline 13 & 0 & 1 & 1 & 0 & 1 & 0 & 0 \\
\hline 14 & 1 & 0 & 0 & 1 & 0 & 0 & 1 \\
\hline 15 & 1 & 0 & 1 & 0 & 0 & 0 & 0 \\
\hline 16 & 0 & 0 & 0 & 1 & 0 & 1 & 1 \\
\hline 17 & 0 & 0 & 0 & 0 & 1 & 1 & 1 \\
\hline 18 & 1 & 0 & 0 & 1 & 0 & 1 & 0 \\
\hline 19 & 0 & 1 & 0 & 1 & 1 & 1 & 0 \\
\hline 20 & 0 & 1 & 0 & 0 & 1 & 0 & 1 \\
\hline
\end{tabular}

Sumber : Aria \& Susilowati (2020)

Data penjualan konektor berdasarkan model disimpan kedalam bentuk excel agar bisa diolah kembali kedalam aplikasi Tanagra.

2. Setelah itu data Excell akan diimport ke aplikasi Tanagra, seperti gambar dibawah ini.

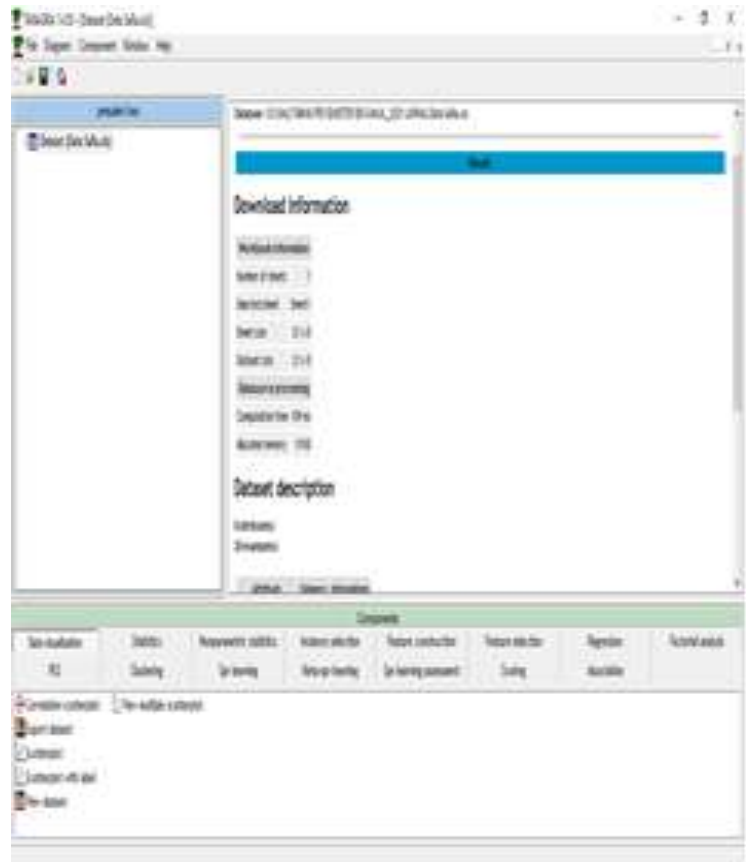

Sumber : Aria \& Susilowati (2020)

Gambar 1 Mengimport data Excell ke dataset Tanagra

3. Data dalam database Tanagra bisa dilihat berdasarkan atribut yang dimilikinya

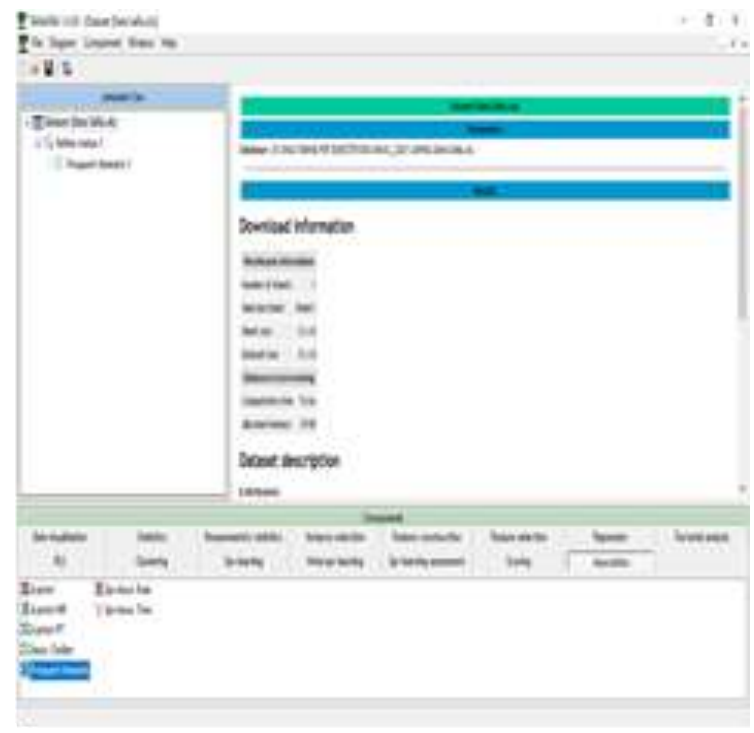

Sumber : Aria \& Susilowati (2020)

Gambar 2 Atribut dataset

4. Kemudian lakukan proses pengujian support terhadap atribut yang ada di data excel, yang bisa dilihat digambar 3 dibawah ini 


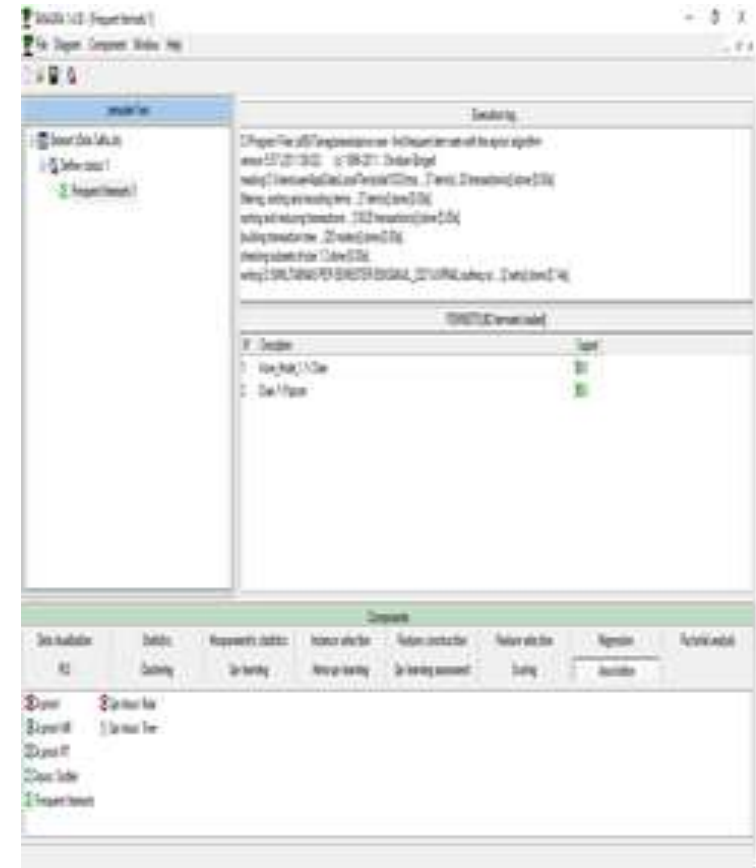

Sumber : Aria \& Susilowati (2020)

Gambar 3. Pengujian Support itemset

5. Setelah hasil dari support dari itemset maka akan dilanjutkan untuk menghitung frekuensi dari itemset, ada digambar 4

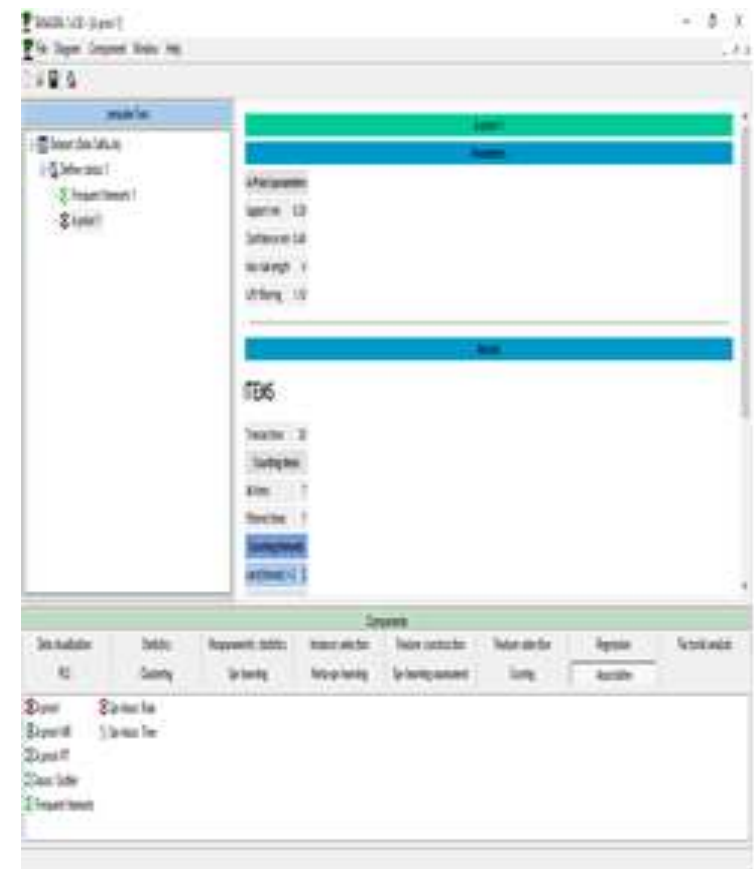

Sumber : Aria \& Susilowati (2020)

Gambar 4. Hasil perhitungan frekuensi itemset

6. Setelah mendapatkan nilai support dan frekuensi maka akan didapatkan hasil asosiasi final sehingga didapatkan hasilnya yang memenuhi min.support dan min.confidence yaitu chain dan popcorn serta buckle dan popcorn, yang ditunjukan digambar 5

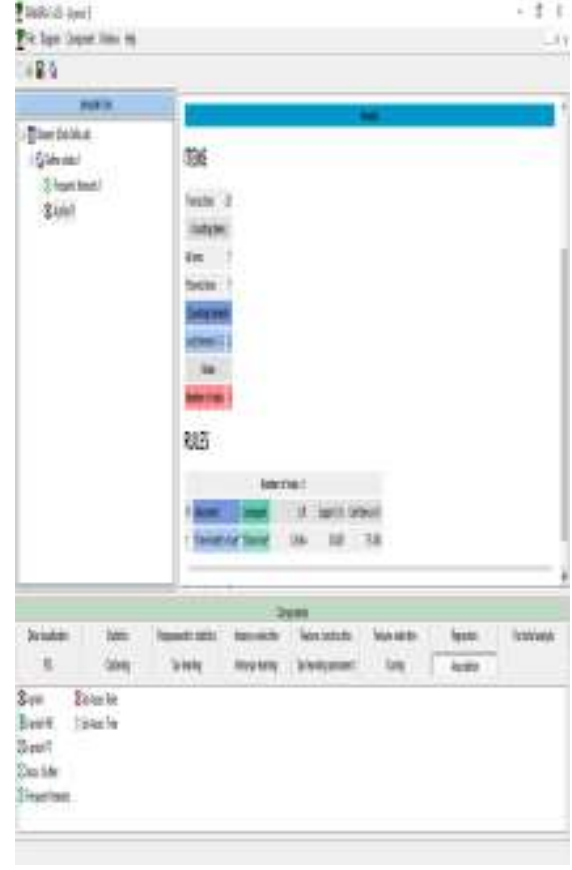

Sumber : Aria \& Susilowati (2020)

Gambar 5. Hasil asosiasi

\section{KESIMPULAN}

Penelitian ini dilakukan untuk mengetahui konektor apa saja yang paling banyak diminati oleh konsumen berdasarkan model yang paling banyak diminati oleh konsumen yang dilihat berdasarkan hasil perhitungan nilai support dan minimum confidences yang dapat membatu pemilik dari SaRa collection dapat menentukan strategi pemasaran dengan menyediakan infromasi mengenai promosi serta adanya laporan mengenai stok konektor yang kosong. Dengan menggunakan perhitungan secara manual dan aplikasi Tanagra diperoleh hasil nilai asosiasi final jika konsumen membeli model chain maka konsumen juga akan membeli model popcorn serta jika konsumen membeli buckle maka akan membeli juga model popcorn.

\section{REFERENSI}

Ariefana Ria Riszky, M. S. (2019). Data Mining Menggunakan Algoritma Apriori untuk Rekomendasi Produkbagi Pelanggan. Jurnal Teknologi Dan Sistem Komputer, 7(3), 103108. Retrieved from https://jtsiskom.undip.ac.id/index.php/jtsiskom /article/view/13234/12516

Bella Audi Najib, N. S. (2020). Penerapan Data Mining Terhadap Data Penjualan Lapis Bogor Sangkuriang Dengan Metode Algoritma Apriori. Jurnal Teknik KomputerAMIK BSI, $V I(N o .1$ 2020), 62. Retrieved from https://ejournal.bsi.ac.id/ejurnal/index.php/jtk/ article/view/6765/pdf 
Halfis, A. H. A. R. S. R. (2019). Analisis Algoritma Klasifikasi C 4.5 Untuk Memprediksi Keberhasilan ImmunotherapyPada Penyakit Kutil. Jurnal Teknik Komputer AMIK BSI, $v(\mathrm{~N} 0.2)$, 155-160. Retrieved from https://ejournal.bsi.ac.id/ejurnal/index.php/jtk/ article/view/4851/pdf

Kusrini, L. E. (2009). Algoritma Data Mining. Yogyakarta: Andi Offset.

Lestari, N. (2017). PENERAPAN DATA MINING ALGORITMA APRIORI DALAM SISTEM INFORMASI PENJUALAN. Jurnal Edik Informatika, 3, 103-114. Retrieved from http://ejournal.stkip-pgri-

sumbar.ac.id/index.php/eDikInformatika/articl e/view/1540

Nurdin, D. A. (2015). PENERAPAN DATA MINING UNTUK MENGANALISIS PENJUALAN BARANG DENGAN MENGGUNAKAN METODE APRIORI PADA SUPERMARKET SEJAHTERA LHOKSEUMAWE. TECHSI Teknik Informatika, 6 No.1, 134. Retrieved from https://ojs.unimal.ac.id/index.php/techsi/article /view/184/166

Purnia, D. S., \& Warnilah, A. I. (2017). Implementasi Data Mining Pada Penjualan Kacamata Menggunakan Algoritma Apriori No Title. IJCIT (Indonesian Journal on Computer and Information Technology), 2(2), 31-39. Retrieved from https://ejournal.bsi.ac.id/ejurnal/index.php/ijcit /article/view/2776

Sianturi, F. A. (2018). Penerapan Algoritma Apriori Untuk Penentuan Tingkat Pesanan. Jurnal Mantik Penusa, 2(1), 50-57. Retrieved from http://e-

jurnal.pelitanusantara.ac.id/index.php/mantik/a rticle/view/330

Sinaga, A. S. R. (2019). Implementasi Data Mining Penjualan Produk Pakaian Dengan Algoritma Apriori. iJAi (Indonesian Journal of Applied Informatics), 4(1), 23-29. Retrieved from https://jurnal.uns.ac.id/ijai/article/view/37989

Ulfha, N. F., \& Amin, R. (2020). IMPLEMENTASI DATA MINING UNTUK MENGETAHUI POLA PEMBELIAN OBAT MENGGUNAKAN ALGORITMA APRIORI. KOMPUTASI: Jurnal Ilmiah Ilmu Komputer Dan Matematika, 17(3), 396-402. Retrieved from https://journal.unpak.ac.id/index.php/komputa si/article/view/2150/1708 